\title{
筑後地方南部における黄檗派寺院の本堂形式とその変遷 SOME TYPES OF THE MAIN BUILDING OF OBAKU-SECT BUDDHIST TEMPLES IN SOUTHERN PARTS OF CHIKUGO DISTRICT AND HISTORICAL TRANSITION OF THESE TYPES
}

\author{
山本輝 雄* \\ Teruo YAMAMOTO
}

\begin{abstract}
This report is a study on some types of the main building of Obaku-sect Buddhist temples in southern parts of Chikugo district and historical transition of these types in Edo-period. In this district at first Daiyuhoden in Fukugonji temple was built in 1674. And a model of this building was Daiyuhoden (built in 1669) in Mampukuji temple which is a center of Obaku-sect temples all over Japan. There were the main buildings having no floor adopted from the age earlier than Bunsei period(1818 30), those called "Zashiki-hondo" and those called Hoojo-type.
\end{abstract}

Keywords : type of the main building, Obaku-sect Buddhist temples, Chikugo district, Daiyuhoden, Mampukuji temple, Fukugonï temple 本堂形式, 黄檗派寺院, 筑後地方, 大雄宝殿, 萬福寺, 福厳寺

はじめに

本稿は，九州地域の一つの特定地方における黄檗派寺 院の中で，本堂形式が江戸時代を通じてどのような歴史 的変遷をしたのかを，具体的に解明しようとする試みで ある。

日本建築史研究が黄檗派寺院に関して解明してきたこ れまでの研究の範囲は, 筆者の研究部も含めて, 長崎 の三つの唐寺, 本山黄檗山萬福寺および各地方での中枢 的寺院（禅堂を 1 つの独立した建物としてもつ寺院）に ほほ限られている就2。今後行われる研究が, 上記の範 囲内に研究を限っていては, 中国明清時代における建築 文化の日本への伝播, 黄檗派寺院に係わる建築文化の日 本での確立, さらには確立した建築文化の日本各地中枢 への伝播という歴史的展開過程の範囲内に限界つけられ ることになると考えられる。黄檗派寺院の建築文化に関 する歴史的展開過程を研究する上では, 上記の範囲外に も, 隠元禅師の法系達によって各地方に伝播し普及し定 着しさらには新たに付加された筈の建築文化にも目を向 けることが重要だと考えられる。

そこで, 本稿での研究対象となる範囲は, 従来の研究 対象に含まれていなかった地方の小寺院が多く含まれる こうになって，史料の収集は困難になる。江戸時代にお ける黄檗派の末寺についての研究は, 平成 2 年 (1990) 6 月になってようやく公刊された黄檗宗末寺帳き3) の研究
から梁まって行くであろう。従来の研究においても，黄 檗派の宗勢については次のように推測される。本山黄檗 山萬福寺が寛文元年 (1661) に現在地で確立した後, 江 戸時代を通じて黄集派の寺院数は爆発的に增え続け，本 山の末寺調へによれば, 延享 2 年（1745）に1043ヶ寺, 文政 5 年 (1822) には 1240 寺となっているき4)。しか し、こうした寺院数の増加が黄檗派の宗勢の拡大と直ち に単純に解釉して良いとは思えない。例えば,「黄檗派 は寛文から元禄にかけて, 爆発的な発展をとげ……(中 略)……，ところが元禄末頃には早くも衰えを見せ始め た」热)との見解もある。黄檗派の宗勢の研究は，末寺帳 の公刊もあったことだし, 今後各方面からの研究が進む と考えられる。一般的に言えば, 江戸幕府は江戸時代前 期から江戸時代を通じて新しい寺院開設は認めない方針

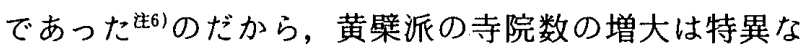
現象と考えられるのである。具体的には, かつては他宗 派であった荒廃寺院や無住寺院などを黄檗派へ転派させ 再興した例が多いと考えられている部。転派し再興し た寺院であっても, 転派以前の他宗派との関係を考虑に 入れれば，黄檗派としての建築文化をもつ寺院なのであ るからここで採り上げ得ると考えて，本稿を試みたも のである。

次に, 本稿において, 何故に筑後地方南部を採り上げ たかを説明しておく。当地方にはいまだ23ヶ寺院もの 
黄檗宗寺院が登録され の中では最も黄檗宗寺院が今日も集中している地方であ る。当地方の黄檗派寺院は, 隠元の法嗣である木庵 (本 山萬福寺第二代住持）からさらに法を跼いだ鉄文道智を 祖とする別峰下に廃寺も含めて全て属していて, 派下別 に考えてもまとまりのある一地域である。派下別黄檗宗 寺院系図 ${ }^{ \pm 99}$ によって全国的に眺めてみると，紫雲派・ 長松下・緑樹下・聖林下等に属した寺院が, 数において 別峰下に属した寺院より多いが, 廃寺となってしまった 寺院も多いし，地域的なまとまりは別峰下のように一地 方に限定されていない。別峰下の寺院は, 当筑後地方南 部の柳河藩領内 (一時, 柳河藩領内に三池藩が分藩独立 したことがあるので，この時代は三池藩領も含む）のみ に限られる。故に，派下別においても，地域的にも，当 筑後地方南部が黄檗派寺院における建築文化の歴史的展 開を考える際には適当な一地方であると考えた次第であ る。

当地方における黄檗派寺院の歴史的展開は, 鉄文禅師 によって当地方の中枢的寺院として梅獄山福厳寺が開設 されて以後，鉄文あるいは鉄文の弟子達を開山として 続々と黄檗派の寺院が開設されて行き注10), 明治 5 年 （1872）10月の文書礼にによれば鉄文禅師を開山とする 寺院 15 ヶ 寺, 鉄文品法の弟子達を開山とする寺院は 12 ケ 寺, その他の別峰下の寺院を加えて, 明治 5 年 (1872) には当地方に黄檗派寺院が 34 ケ寺存していたことにな

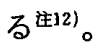

これらの黄檗派寺院において, 寺院規模の大小にかか わらず，寺院の本尊を祀るための堂すなわち本堂が，全 ての寺院に建てられたと考えられる。そこで，本稿は， これらの本堂の形態面での形式を本堂形式と考えて，こ の本堂形式が江戸時代を通じて当地方においてどのよう に変遷したのかを具体的に解明することを研究の目的と する。そのために，今日まで保存されている江戸時代の 本堂を平面について実測調查し，立面や建築細部の形態 を調查し，これらの本堂の建設年代を知る史料を収集し た。次に，本堂の建物は残っていないが，平面のみは判 明する古絵図を特に旧柳河藩主家（立花和雄氏）蔵に探 し出した。本山に保管されている明治 13 年 (1880) 頃 の『寺院明細帳』に載っている本堂の間取り図は, 明治 時代に入ったものと言っても，参考になった。その他， 残る写真によって, 外観や内部を知ることができる本堂 もある。各寺の歴史については，「鐵文樿師語録』は拠 るべき史料と考えられるが，地誌䫛なざその他の史料は 寺伝に止まるものが多い。

こうして収集した資料を整理して, 当地方における黄 檗派寺院の本堂全てを，以下のような本堂形式にまず分 類した。次に, 各本堂形式に含まれる各々の本堂の建設 年代について考えて, 各本堂形式の出現した時期につい
て考察した。そして, 筑後地方南部における黄梁派寺院 の本堂形式とその変遷について, まとめた。

\section{各本堂形式}

1. 梅獄山福厳寺の大雄宝殿

筑後地方南部における黄檗派寺院の歴史は, 梅狺山福 厳寺（柳川市大字奥州町 32-1）加ら始まっている。当 寺は, 曹洞宗の梅岳寺が空寺であったのを, 柳河藩主が 当地出身の鉄文道智を迎えて開山として黄檗派としし，寺 名も改めて梅獄山福厳寺と名付けて再出発させた寺であ る(13)。開山・鉄文禅師が当寺に入院したのが寬文 9 年

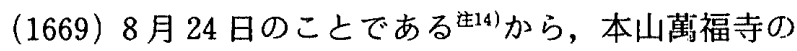
創建の寛文元年 (1661) からわずか 8 年後のことであり， 全国的に見ても早い開始である。

『鐵文禪師語録】音15)巻第一の「住筑州山門縣梅岳山福 嚴禅寺語録」によれば，冒頭の開山入院にあたって開山 が「山門」「佛殿」「伽藍堂」「祖師堂」「方丈」において 法語を示したことになっている。『鐵文禪師語録】にの み記載されているところの入院式における「佛殿」がど のような建物であるのかは全く知ることができない。鐵 文禪師語録』巻第十二の「行状」によって知られるよう に，この入院から 13 年目の延宝 2 年 (1674) までには 大雄宝殿等が落成しており先16)，『鐵文禪師語録』巻第一の先述の入院法語に続いて書かれている「新殿樂成」し て柳河藩主等が鉄文禅師に開堂をお願いしていることを 延宝 2 年 (1674) のことと判断して, 福厳寺大雄宝殿は この延宝 2 年（1674）までに新たに建設された建物と考 えられる。が，この大雄宝殿は現存しない。明治時代始 めの頃解体されたと伝えられる大雄宝殿に安置されてい た「大雄宝殿」の大額 $(300.0 \times 126.7 \mathrm{~cm})$ ，巨大な対 聯 $(1$ つが $371.0 \times 35.0 \mathrm{~cm})$, 釈迦 - 阿難・迦葉の 3 像 および大前机などは現本堂に安置されている。寺伝では, 大雄宝殿が火災にあったり再建されたりしたということ はない。そこで，延宝 2 年 (1674) までに落成した大雄 宝殿と思われる建物の平面は, 立花和雄氏蔵の寬政元年 (1789）改めの『福厳寺惣地指図』中に描かれていると 考えられる。これは土間式の建物と考えられ，「本堂」 と表示されているき17)。この平面図 (図一1)に見られる ように，殿内は正面五間・側面六間の規模であり，前面 一間通りの通路部分が付設している。この前面一間通り の通路部分の前列柱が左右へ連なる廊下の柱より明らか に大きく描かれていることから判断して，本山郇福寺(D

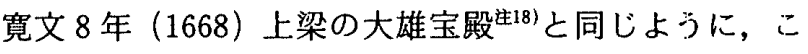
の前面一間通りの通路部分は構造的にも大雄宝殷の建物 の中に取り込まれていたと考えられる。

以上のように, 梅獄山福㛜寺の大雄宝殿は, 本山萬福 寺の大雄宝殿と平面についてはよく似た建物であったよ 考えられる。平面の細部についての違いを揭げるとすれ 


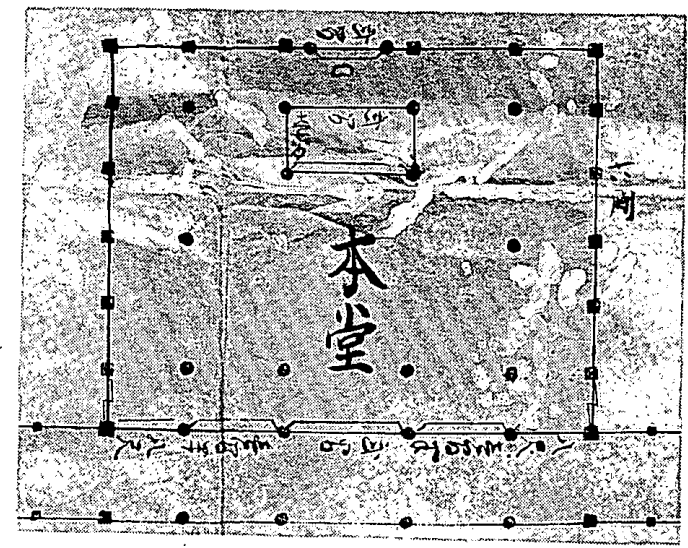

图一1 「福厳寺惣地指図」(立花和雄氏蔵) 中の福厳寺大雄宝殿

ば，本山萬福寺の大雄宝殿が角柱のみ使用しているのと 比べると, 福厳寺の大雄宝殿は中央部あたりに丸柱の使 用が認められることである。

福厳寺大雄宝殿の立面は, これを直接的に知り得る資 料を今日もたないが，本山萬福寺大雄宝殿との関連の中 で，次のように推測することが可能と考えられる。

まず，伽藍構成については，福厳寺が先記の寬政元年 （1789）の『福厳寺惣地指図』に示してあるように本山 萬福寺と同様な所謂コの字型の伽藍構成をしていたこと はすでに拙稿で指摘した ${ }^{\sharp 11}$ が，さらに両寺の伽藍構成 が同じであることを考える鉄文禅師の詩偈についての検 討はここでの問題と直接関連しないので別稿㐫199に譲る。 このように, 福厳寺は本山萬福寺と同じく, 大雄宝殿を 中心にして左右に禅堂と斎堂を配する所謂コの字型の伽 藍構成をしていたのである。

大雄宝殿のみについても, 福厳寺と本山萬福寺の関連 をうかがう文言は，大雄宝殿に揭げられる対聯に見られ るのである。本山犬雄宝殿の対聯文言は，「黄檗清規」 にあるように「紺殿荘厳仏日を光す」と記してあって, 大雄宝殿の建築としての荘厳化が示されていると考えら れるのに対して, 禅堂・斎堂のそれらは修行する僧侶に 対する精神的な心構えを示しているき20)。他方, 福厳寺 の対聯は全て木庵の書であるが, 大雄宝殿のそれは「紺 碧雄宮瑞彩氮氳として」となっており大雄宝殿のみは建 築としての荘厳化が表明されていると考えられるのに対 して, 禅堂・斎堂のそれらは精神性についてのみ述へて

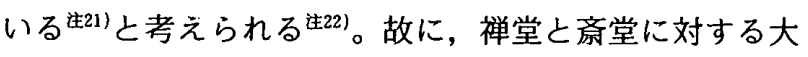
雄宝殿のみの荘厳化が, 福綮寺大雄宝殿と本山萬福寺大 雄宝殿には, 各々の対聯文言に同様に表れていると考え られる。

そこで, 福厳寺大雄宝殿の外観は, 平面規模の大きさ に加えて, 本山萬福寺との比較において大雄宝殿の平面, 大雄宝殿に揭げられた対聯文言の内容および伽藍構成が 類似していることから, さらに福厳寺開始の歴史から判 断しで, 本山萬福寺大雄宝殿と同じような外観屋根二重
のものであったと推測される。

大雄宝殿という建物名は, 当地方の黄檗派寺院では, 当寺に限って用いられている。大雄とは伀陀の称号注23) であるから，大雄宝殿とはお釉迦様をお祀りする堂宇に 対する美称と考えられ，一般的用語とも思われる。しか し, 当地方において, 今日までの調査では, 後述する全 ての本堂について, 本尊が釈迦像である場合でも, 大雄 宝殿と呼ばれたことはない。

以上述べてきたように，歴史的に見れば福厳寺は当地 方での黄檗派の始まりの寺院としてとらえられるし，形 態上あるいは建物名から見ても福厳寺大雄宝殿のみは本 山大雄宝殿との直接的関係の中で当地方において発生し たと考えられ，後述する各形式の本堂とは異なると考え られるので 1 分類として先ず第 1 に揭げた。そして，こ の福厳寺大雄宝殿こそは延宝 2 年（1674）までには当地 方にはじめて出現した本堂形式と考えられるのである。 2. 土間式本堂

江戸時代において当地方の黄堭派寺院の本堂が土間式 の本堂であったと確認される寺院は, 前記福厳寺大雄宝 殿を除くと, 見存の建物で 3 ヶ寺, 江戸時代の絵図や写 真として記録に残るものが 2 ケ寺であり, 合計わずかに 5 ヶ寺のみである。なお，本山萬福寺所蔵文書中の明治 13 年 (1880) 頃の『寺院明細帳」せ44)には当地方のほぼ 全寺院の本堂の間取り図が付載されているが，これらの 図中にも上記以外の寺院に土間式の本堂は見当たらな (亦25)。

判明した 5 ヶ寺における土間式の本堂は仏殿と記して いる本堂もある。これら 5 ヶ寺の本堂は福厳寺大雄宝殿 と同じく土間式であるが；別の 1 分類として揭げている のは, 福㛜寺の土間式の本堂のみ大雄宝殿と称され, 後 述するように平面規模は福厳寺大雄宝殿よりずっと小さ く, 外観は全て一重の屋根と考えられて福厳寺大雄宝殿 の外観屋根二重と推測されるのとは形態面で異なると考 えられるからである。加えて, 寺全体としては, 伽藍構 成および黄檗派寺院としての歴史的位置づけが異なるこ とも, ここでの 5 ケ寺の土間式の本堂と福厳寺大雄宝殿 を分類分けした理由である。

そして, 本稿ではこれら 5 ヶ寺の土間式の本堂形式を 土間式本堂と名付けた。

以下，土間式本堂の実例について考察する。

イ. 竜首山法雲寺の土間式本堂

昭和 34 年 (1959) 焼失するまで土間式本堂のあった 竜首山法雲寺 (大车田市倉永 872) は, 同地にあった崇 勝寺を東後方に移転させ，同地に鉄文を開山として延宝

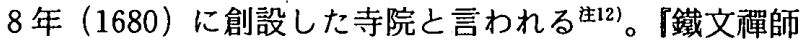
語録」巻第十二の「行状」には「(延宝) 庚申年太守源 公新創龍首山法雲禪寺。延師為開山初祖。」とあって; 延宝 8 年 (1680) 柳河藩主によって当寺が新創されたこ 
とが記されている。昭和 34 年（1959）まで保存されて いた土間式本堂は, 同寺に残る写真による細部形態の年 代推定上り，江戸時代後期の建物と思われる。

当法雲寺の江戸時代における土間式本堂の平面を描く 図が 2 枚ある。立花和雄氏蔵の寛政 2 年 (1790) 改めの 『倉永法雲寺】図と伝習館文書中の江戸時代後期頃と思 われている「寺社古絵図」中の「法雲寺」図である。両 者はほぼ同じ間取りをしており，より詳しい前者の図を 揭げる。当図（図一2）には最前列の柱が 5 本描かれて いるが，「法雲寺』図には見えない右から2本目の柱が 間違って付け加えられた柱と考えると, 平面の規模は前. 面三間・側面七間である。「土間佛殿」と表示してある。 中央部を丸柱として, 四周に一間通り角柱を题して内部 空間とする。前面には一間通りの空間があるが, 殿内は 建具が描かれる前方より 2 列目の柱列より内と思われる ので,この前面一間通りは吹き放しと考えられる。中央 奥に仏壇, 両側壁に脇仏壇, 左側面奥の方に突出した「佛 道具入」が描かれるが，この「佛道具入」は出入口が外 部に取り付けられている。「鐵文樿師語録」にある唐匠 游君亨の彫った十八大阿羅漢像は両脇仏壇に置かれてい たのであろう。当図に描かれた「土間佛殿」は土間式本 堂であり, 福厳寺大雄宝殿の寛政元年 (1789) の図と較 へると，規模はずっと小さいが，平面計画については前 面一間通りに吹き放し部分をもつことや中央部分に丸柱 を使用することなどは同じである。

この図における平面のあり方や規模は，残る写真から 判断すると, 昭和 34 年（1959）まで保存されていた土 間式本堂とほぼ等しい。しかし, 昭和 34 年 (1959) ま で保存されていた土間式本堂の細部形態が，図の寛政 2 年 (1790) までさかのぼれるかどうか即断できない。が, たとえ再建であったとしても，建築形式は引き継がれた と推定される。

昭和 34 年（1959）まで保存されていた土間式本堂は,

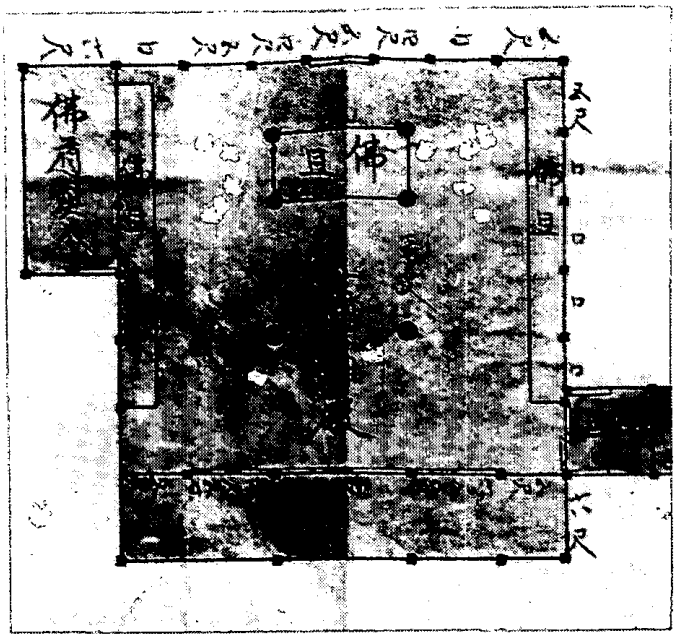

图一2 『倉永法雲寺図」(立花和雄氏蔵) 中の法雲寺の土間式本 堂
残る写真によると，立面は草直寄棟屋根の本体があり， 前面一間通り吹き放し部分には一段低い位置に瓦惪の牌 流れの屋根が付いている。

さらに遡って創建の当寺仏殿がどのような形式であっ たのかを考える資料はない。が，当寺には火災等の伝え は昭和 34 年 (1959）までなく，唐匠の彫った羅漢像も 昭和 34 年 (1959) まで土間式本堂内部の両脇仏壇に经 置されていた。創建の仏殿が莧政 2 年 (1790) の図にあ る「土間佛殿」や昭和 34 年 (1959) まで保存されてい た土間式本堂と同じ本堂形式であったことは推測され る。

口. 泰雲山崇勝寺の土間式本堂

泰雲山崇勝寺（大牟田市倉永 1255）は, 前記法雲待 のすぐ近くに所在する。古来曹洞宗に属し旧名を弘済待 と称していたが，現在の法雲寺の寺地にあった侍を鳳来 寺という寺跡の現在地に移転したものであり，貞享 4 年 （1687）鉄文禅師を開山として黄檗派に帰し崇勝寺と称 したと言われる文12)。創建については延宝 5 年 (1677) 10 月と貞享 4 年 (1687) の二つの説が揭げられている 後世の記録もある站。

現在, 宝形造瓦葺の床を張る一室の独立した本堂一宇 が保存されている。当堂は復元すると, 現位置で土間式 本堂であったことが判明する。推定復元平面函は図一-3 の通りである。平面は正面三間・側面六間であり, 内部 の中央の 4 本の柱が円柱であることや前面一間通りに吹
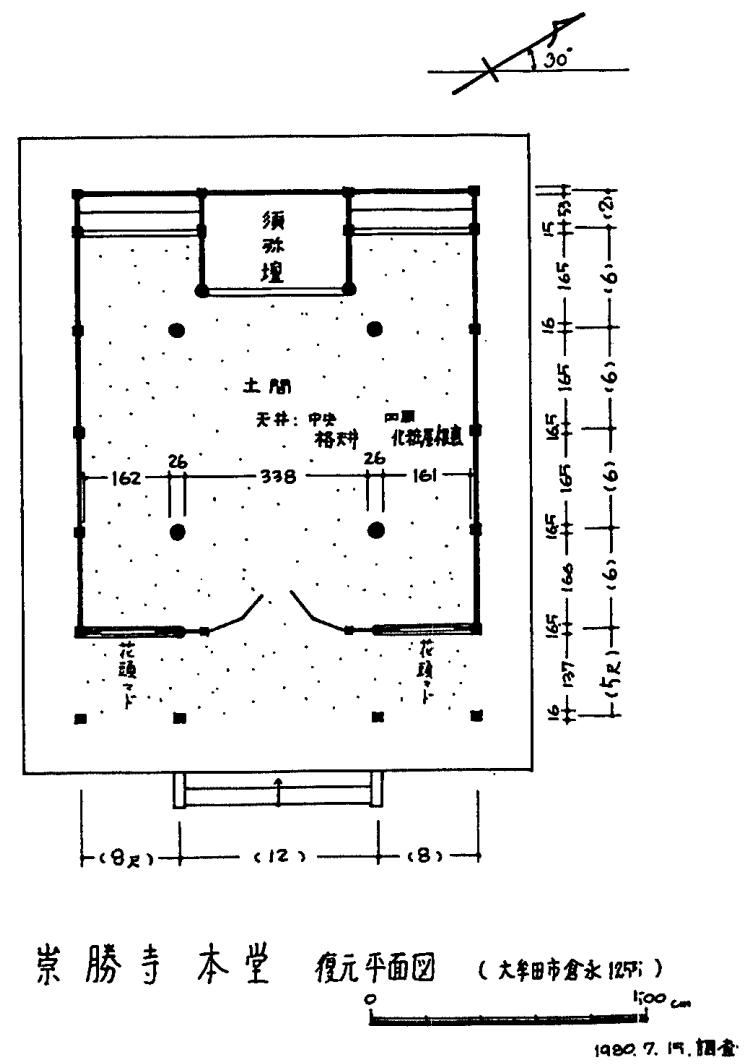

図一3 崇勝寺の土間式本堂の推定復元平面図 (筆者製図) 
き放し部分をもつことなど，前記法雲寺古図の「土間佛 殿」と形式が同じである。調查と聞き取り調查で，立面 は草直寄棟の一重屋根の本体に前面の一段降りた位置に 瓦直の片流れの屋根が付いていたことが判明した。当寺 の土間式本堂は，平面については法雲寺古図の「土間佛 殿」と, 立面については昭和 34 年 (1959) まで保存さ れていた法雲寺の土間式本堂とよく似ている。この崇勝 寺の土間式本堂の建設年代は，山門外立石（昭和 57 年 に法雲寺へ移設）の紀年銘にある文政 11 年 (1828) 頃 のものと, 細部形態より推定される。

「鐵文禪師語録」巻第三の「住筑州三池縣泰雲山崇勝 禪寺語録」によると，延宝丁巳年（五年=1677）泰雲山 崇勝禅寺の入院式にあたって, 法語を示した場所が,「山 門」「佛殿」「伽藍堂」「祖師堂」「方丈」に及んでいる。 この語録によると崇勝寺は延宝 5 年（1677）に鉄文禅師 によって開始されたことになり，既に記した寺伝を併せ 考えると延宝 5 年 (1677) には崇勝寺は現在の法雲寺の 地にあったことになるが，この「佛殿」については何も 知ることができない。なお，後世の記録として既に記し た貞享 4 年 (1687) 創建というのは，現在の地において の創建を示しているのかもしれない。いずれにしても， 延宝 5 年（1677）の『鐵文禪師語録』に見える「佛殿」 ならびに現在地において創建された本堂については，そ れらの形式は全く不明である。

現存の同寺土間式本堂は, 文政 11 年 (1828) 頃の建 物と推定されるが, 前記法雲寺の判明する土間式本堂と 平面之立面の類似が認められる。なお，この建設の推定 年代は創建よりずっと遅れるので，旧宗派との関係は考 虑に入れなくてもよいと考えられ，黄檗派寺院としての 本堂として現在地に再建されたものと考えられる。

八. 大慈山苇日寺の土間式本堂

大慈山憲日寺 (大车田市大字岩本 2589) は, 净土宗 の寺院を, 延宝 5 年 (1708) 鉄文の法嗣・霊峰元秀が転 派させて，黄檗派として開設した寺院であると言われ る $^{\text {i212) }}$

現在の本堂の平面は図一4のような土間式本堂であ る。平面の形式は，既に述へてきた古図の法雲寺「土間 佛殿」や宗勝寺本堂の推定復元平面と同じである。正面 三間・側面六間であり，丸柱がかなり多く使用されてい るが，前面一間通りは例によって吹き放し部分となって いる。ただし，立面は一重・入母屋造・本瓦苜であり， 前面一間通り吹き放し部分も本体の屋根がそのまま苜き 降ろしとなっている。

当堂は寺蔵の 2 枚の棟礼 ${ }^{\circledR 26)}$ によって,宝永 5 年(1708) に創建されたが，延享 2 年（1745）に再建され，さらに 天保 10 年 (1839) に建築された「観音宝殿」と考えら れる。建築細部の形態もこの天保頃のものとされてい る(27)。
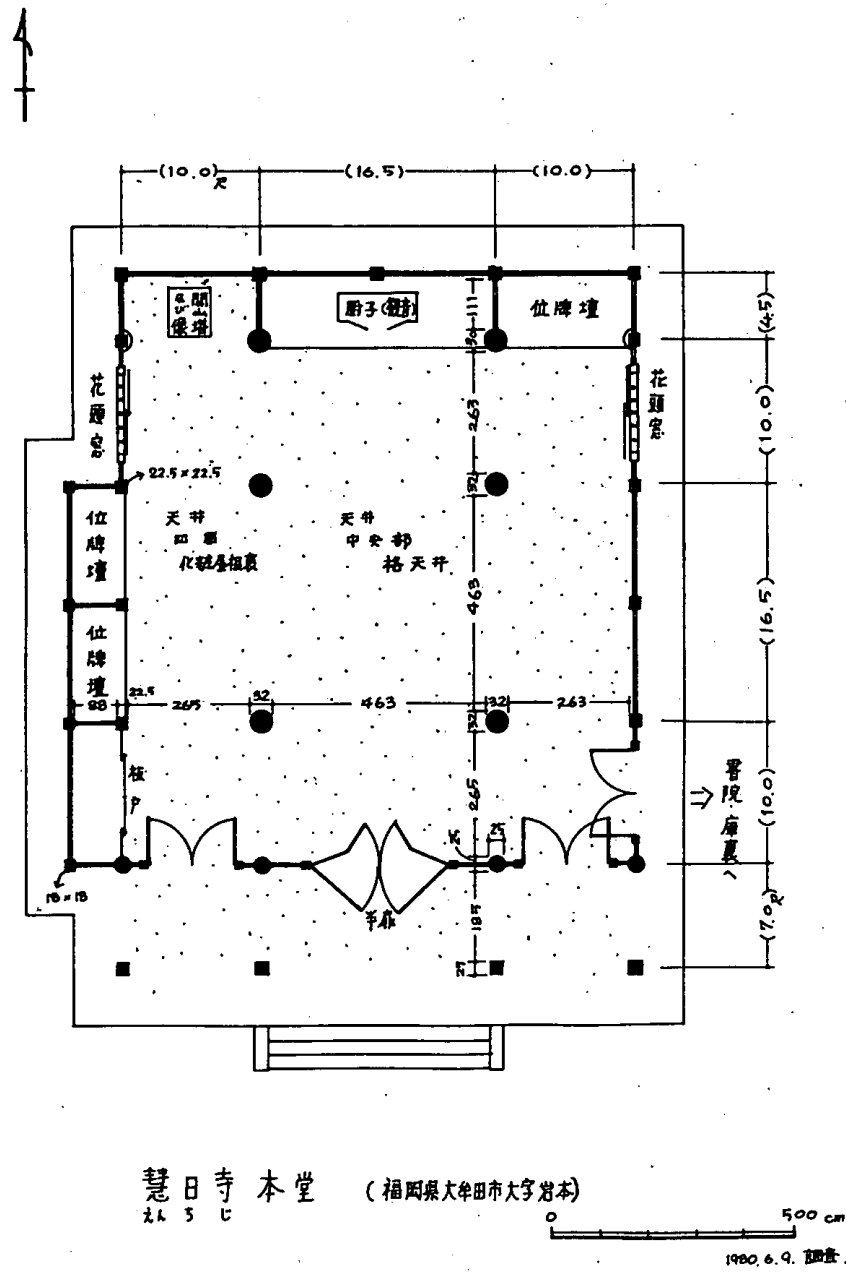

図一4 慧日寺の土間式本堂の現状平面図（筆者製図）

本尊が観音であるのは転派以前の寺院から引き継いだ ものであろう。

同寺は山内寺院を現在も 3 ケ寺ももつ程の大寺院であ るが, 福厳寺のように禅堂・斎堂を独立した建物として もってはおらず，ために所謂コの字型の伽藍構成もして いない。当「観音宝殿」が筑後地方南部における黄檗宗 寺院の現存の土間式本堂では最大規模のものである。図 一1に揭げた寞政元年（1789）の福厳寺大雄宝殿と較べ ると，奥行きは僅かに勝るが正面幅がずっと小さい。平 面形式については，中央部に丸柱を用いることと前面一 間通りに吹き放し部分を付設することは，図一1の福厳 寺大雄宝殿, 図-2 の旧法雲寺仏殿, 図一3の崇勝寺の 復元した土間式の本堂と同じである。

転派する以前の净土宗と当土間式本堂との関連では本 尊については考えられるものの, 本堂形式については浄 土宗とは関連がなく黄檗派との関連で捉えられると考え られる。

\section{二. 瑞雲山聖寿寺の土間式本堂}

瑞雲山聖寿寺（柳川市大字西魚屋町 52-1）は，曹洞 宗の寒山寺を改めて寛文 9 年 (1669) 黄檗派に転じ開山 を鉄文禅師とし明和 5 年 (1768) に現在地に移り寺名も 
聖寿寺と改めたと言われる主28)。現在の本堂は近年改修 があったが，土間式本堂のおもかげは残す。江戸時代の 最末期の部分も残る。明治 13 年 (1880) の『寺院明細 帳』注24)に載る略図には「本堂五間五間 瓦敷」とある。 現在もある前面一間通り吹き放し部分は江戸時代からの 踏襲であろう。現状の栈瓦苜の立面は，慧日寺本堂と同 じであり,一重, 入母屋造である。

ホ. 雪峰山霊明寺の土間式本堂

雪峰山霊明寺（福岡県山門郡山川町河原内）は, 昭和 55 年（1980）6月の「黄檗宗寺院名簿』には記載されて いたが, 現在は名簿からもその名を探し得ない。寺地に は現在も立派な旧柳河藩主の墓所も残る。鉄文を開山と

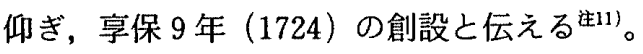

当寺の土間式本堂は, 古図に残るのみである。立花和 雄氏蔵の『雪峰山図』中の「佛殿」がそれである。当古 図は, 既に引用した福厳寺や法雲寺の立花和雄氏蔵の各 古図と同じ寛政年間 (1789～1801) 頃のものと思われる。 この「佛殿」(図一5)は，上記したいずれの土間式本堂、 よりさらに小規模となり, 正面三間・側面三間の奥壁に 仏壇を置いたものであり，前面と側面に通路を付設した 平面である。脇仏壇も構えているが，内部には柱は立た ない。前面等に通路空間を設けているのは, やはり他の 土間式本堂と共通している。使用の柱が全て円柱に描か れているが, 同古図中の他の建物が角柱で表現されてい るので，当「佛殿」の図の円柱表示は実態を反映してい るものと考えられる。

へ. まとめ

以上, 福厳寺大雄宝殿以外の 5 例の土間式本堂は, 当 地方の中枢的寺院である梅獄山福爰寺のそれと, 平面形 式において類似している。中央部分において丸柱を使用 すること（霊明寺の土間式本堂には内部に柱がないが, 丸柱を全面的に使用）および前面一間通りに吹き放し部 分を付設することである。前者の丸柱の採用は，本山萬 福寺の大雄宝殿においては見られないので, 福厳寺にお いてまず採用されたのち，この福厳寺大雄宝殿のあり方 を受け入れたものであろう。後者の前面一間通り吹き放 し部分の採用は，福倣寺大雄宝殿のように禅堂や斎堂へ

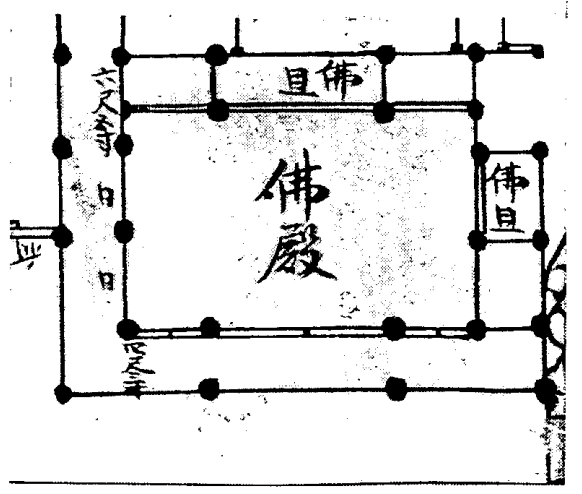

図一5「雪峰山図」(立花和雄氏蔵) 中の霊明寺の土間式本堂
の通路としての機能をもたずとも, 他寺の 5 例では全て 採用するという徹底ぶりを示している。

ただし, 福厳寺大雄宝殿と他の土間式本堂との違いは, 内部に柱をもたない霊明寺の土間式本堂を除いで, 堂内 にある柱で囲まれる中央部分が福厳寺大雄宝殿のみは正 面 5.0 間側面 4.0 間であって横長であるのに対して, 他 の 4 つの寺の土間式本堂は全て正方形となっている。故 に,これら 4 つの寺の土間式本堂は, 全体の平面が奥行 き深くなるのである。

立面においては, 法雲寺・崇勝寺および慧日欮の土間 式本堂において判明したように屋根が一重であり，福孷 寺大雄宝殿で推測したような外観屋根二重ではない。

当地方における黄檗派寺院数全体から見ると, 土間式 本堂の実例は福厳寺大雄宝殿を含めても 6 ケ寺之少ない が, 霊明寺仏殿のような小規模な本堂さえ土間式であっ 、た例から考えて，鉄文や彼の弟子達が開設した名寺院に おいて建てられた創建の本堂のかなり多くが土間式本堂 であった可能性は高いと考えられる。

3. 床を張る一室の独立した本堂

江戸時代を通じて, 筑後地方南部における黄璧派寺院 の本堂の全てが土間式の本堂ばかりであった訳ではな い。黄檗派寺院に関する従来の研究からは本堂は土間式 であると考えられがちであるが，全く注目されていない 林を張る一室の独立した本堂も見られる。

慈観山禅林寺（福岡県山門郡山川町大字河原队）は, 宗派不明の慈観院を元禄 2 年 (1689) 鉄文禅師が福㛜持 の末院としたが末だ再建に及ばず久しく空院で汸ったの を，鉄文の法孫である泰陽净至が中興して今の地に移し 寺名も禅林寺と改めたと伝える望299。

本堂（写真一1）は入母屋造，一間向洋付き，銅板主 である。平面は図一6のように，正面三間・側面四間・ 一間向拝付きである。南面している。前面に板縁が付き, 内部は一室である。堂内の奥壁に一段高い奥行半間の仏 壇を設け本尊と位牌を祀る。仏壇前方半間幅は板敷。さ らに前方はこの板敷と同高の盢 14 帖敷き。東側壁をは り出させて脇仏壇等を付設している。天井は横方向の棹

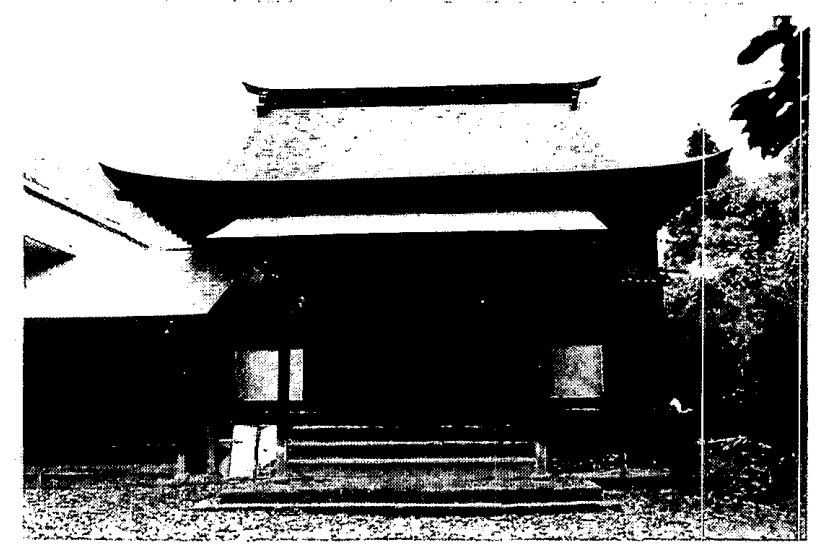

写真一1 禅林寺本堂の正面 (筆者撮影) 


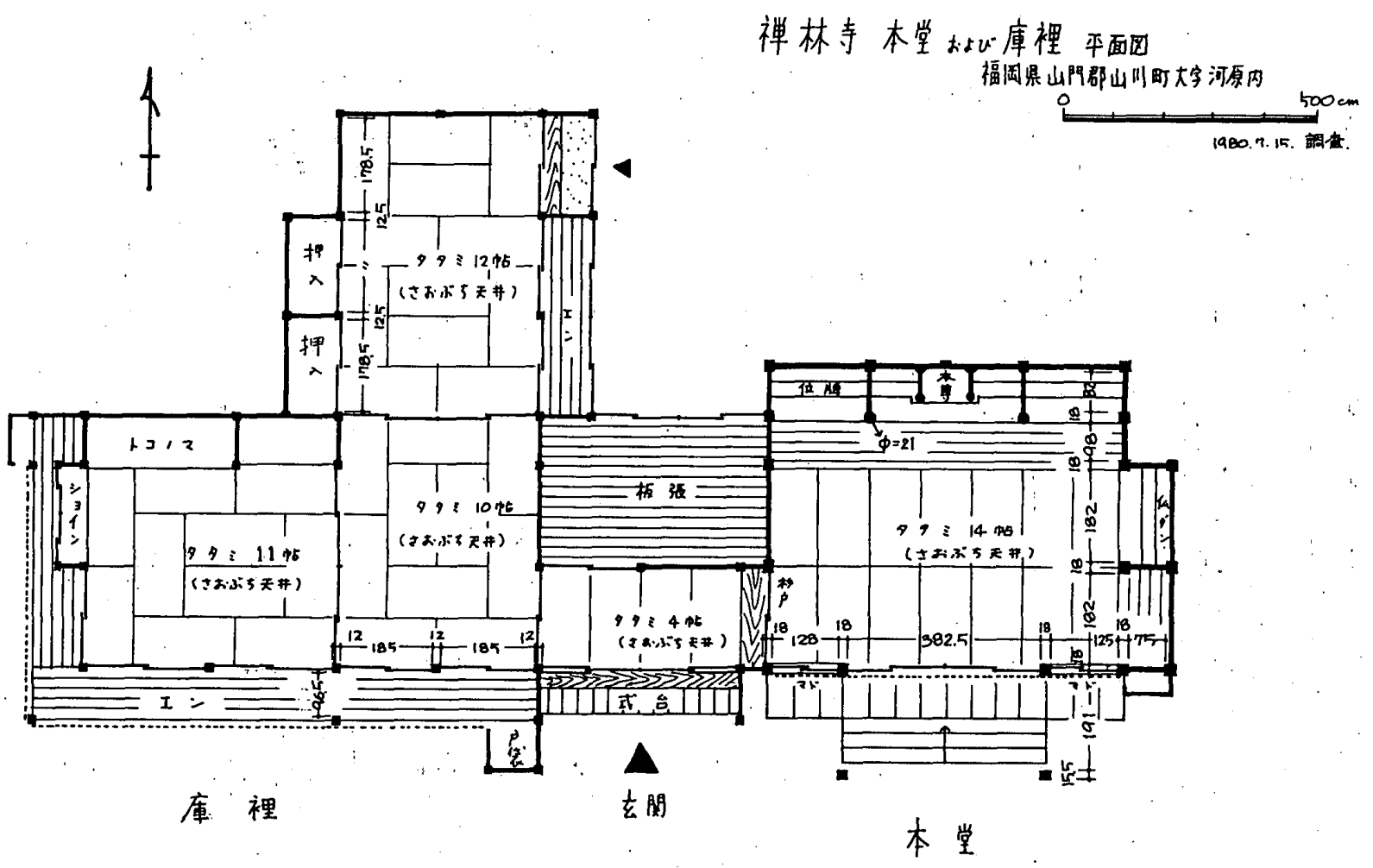

図一6禅林寺の本堂などの現状平面図（筆者製図）

縁天井が一律にはられ堂内はまったく一室扱いとなって いる。丸柱の使用は堂内奥の中央仏壇両脇のみである。 当本堂は，すぐ横の式台付き玄関奥の畳 4 帖敷きの室を 通じて別棟の庫裹へと連結はしているが，平面的にはほ ぼ独立しており，構造的には独立の棟となっている。当 禅林寺本堂は建設当初より犬きな改造は行われておら す，当初よりこのような床を張る一室の独立した本堂で あったと考えられる。当本堂の建設年代は，玄関・書院 とも同年代のものと思われるが，寺号の扁額銘および本 堂内に揭げられる対聯の製造墨書銘にある文政 5 年 （1822）頃のものと考えられ，当推定年代に建築の細部 様式も合う。

隣接する同時代の書院と比べると床高や内法高が高 川。床高は書院が約 $63 \mathrm{~cm}$ に対して本堂は約 $120 \mathrm{~cm}$ で あり, 内法高は書院が $173.5 \mathrm{~cm}$ に対して本堂は 197.0 $\mathrm{cm}$ である。しかじ, 堂内の構成は畳敷き・杉戸を含む 建具・棹縁天井および漆喰壁など住職等僧侶の日常的な 生活空間である庫裏と同じである。

当禅林寺本堂の推定建設年代の文政 5 年 (1822) は, 当寺を現在地に中興した黄檗派の僧・泰陽净至の寂年で ある享保 4 年 (1725) 4 月 15 日文30) 加らさらに百年もたっ ており,調査の結果他所からの移築も考えられないので, この本堂は黄檗派寺院の本堂として同地に建てられたも のと考えられる。

この禅林寺本堂のような, 林を張る一室の独立した本 堂がいつ頃から黄檗派寺院の本堂として当地方で採用さ れたか史料がなくて明確とはなし得ないが，遺構で見る

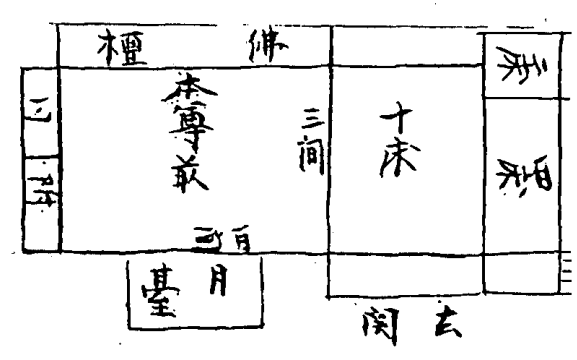

图一个寺院明細帳」(本山萬福寺文華殿蔵) 中の宗永寺本堂

限り, 当禅林寺本堂が最も古い。

このような床を張る一室の独立した本堂を今日採用し ている寺院は多いが，この中で建設年代が江戸時代まで 遡ると考えられる本堂は，この禅林寺本堂以外には見当 たらない。

本山萬福寺所蔵の明治 13 年 (1880) 頃の『寺院明細帳】 で探し出しても, わずかに春林山宗永寺本堂の平面の略 図(図一7) 加同形式と思われるくらいである。当宗永 寺本堂も禅林寺本堂と同じく南面し，玄関を挟んで書院 と連結している。本堂は正面四間側面三間であって奥壁 に接して仏壇を設ける。側面に突出する「附」とは附属 室という意味であろう。前面に書かれている「月臺」と は, 同じ『寺院明細帳】に記載の仏頂山正法寺（後出） の平面図中の式台をもつと思われる玄関にも「月臺」と 書かれているところからみると, 本山萬福寺の大雄宝殿 前方の月台のことではなくて，低い床がある突出部を指 していると考えられる。そのように「月臺」を捉えれば, この宗永寺本堂も禅林寺本堂と同じように床を張る一室 


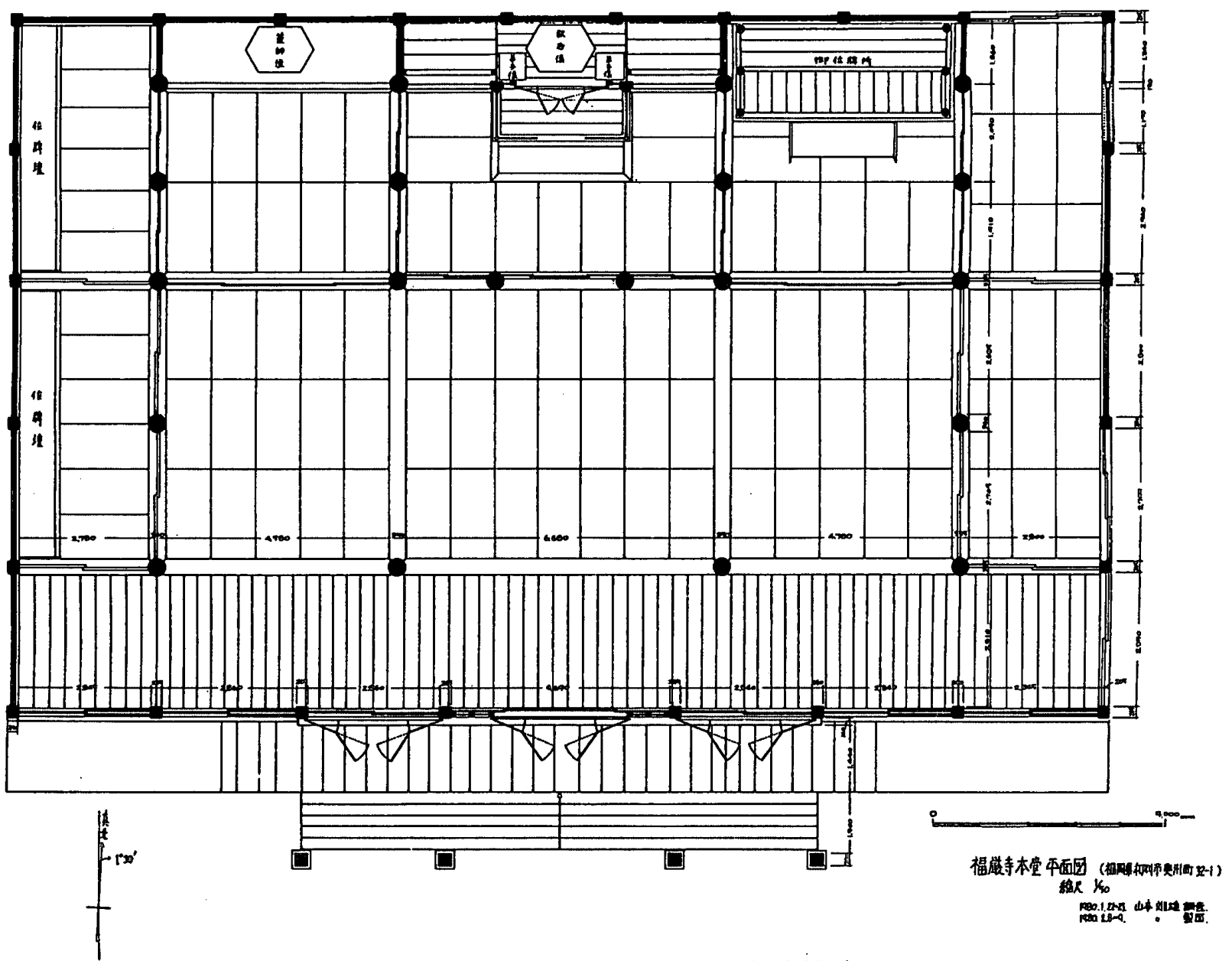

图一8 福厳寺の現本堂の見状平面図（筆者製図）

の独立した本堂である。玄関を挟んで書院と連絡してい る構成も禅林寺本堂と同じである。簡単な略図であるた め正確な判断はできないので, この宗永寺本堂は土間式 本堂である可能性もある。

休を張る一室の独立した本堂と名付けた本堂形式は, 土間式本堂に見られたように完全に他の建物と切り離さ れて独立している訳ではなく, 平面的には玄関の間と連 なって畳敷きの住職など僧侶の日常的生活の場である書 院や庫裏などに無理なく連結されている。

江戸時代における他宗派においても, 当地方において, このように小規模の本堂でありかつ床を張る一室の独立 した本堂が晃られる。例えば前に引用した伝習館文庫藏 の『寺社古絵図』中, 黄檗派寺院でない『谷川寺』の本 堂にもこの本堂形式は胃られるので,この本堂形式が黄 檗派寺院独自の本堂形式とは考えられない。しかし, 多 くの近世社寺調査報告での指摘は極めて少ない。

\section{4. 方丈型の本堂}

次に, 二列三間六室の長方形平面をもつ方丈建築の基 本的間取り ${ }^{\text {注11 }}$ と平面の形態が似ている本堂形式がある。 黄檗派寺院においても, 早く本山萬福寺の方丈において 同じような間取りをもつ建物が採用されている。しかし， これら黄檗派寺院における方丈と中世から続いてきた二
列三間六室の長方形平面をもつ方丈建築との係わりは今 後の課題である。

そこで, 当地方の黄檗派寺院にみられる同じような平 面をもつ本堂形式を方丈型の本堂と名付けて, 以下の建 物について考えてみる。

\section{イ、梅獄山福綮寺の現本堂}

前出梅獄山福厳寺において今日本堂と呼んでいる建物 は, 平面図 (図一8) に示すように, 前面の向抙を除くと, 三面に入側を巡らした二列三間六室の方丈建築の基本型 の間取りであり，この間取りからこの建物は江戸時代に おける禅宗寺院の本堂でもよく見かける二列三間六室の 方丈型本堂 ${ }^{\ddagger 32)}$ の 1 例に入れられるとも考えられる。

が, 当堂は寺蔵の棟札原本によって, 文化 10 年 (1813) 上棟の「祠堂」と考えられ，この「㣁堂」は前記した寛 政元年（1789）の『福厳寺惣地指図』に見る「薬師堂」 （図一9）の平面と機能を踏襲した建物であって，位置も 同位置に建っている。この「薬師堂」には向拝も付加し ていないので, 方丈型本堂の基本的な間取りとなってい る。

そして，この現在の本堂すなわち「而堂」が建った文 化 10 年 (1813) には，まだ土間式の本堂である大雄宝 殿が当堂の前方に貨え建っていたのである。だからこ 


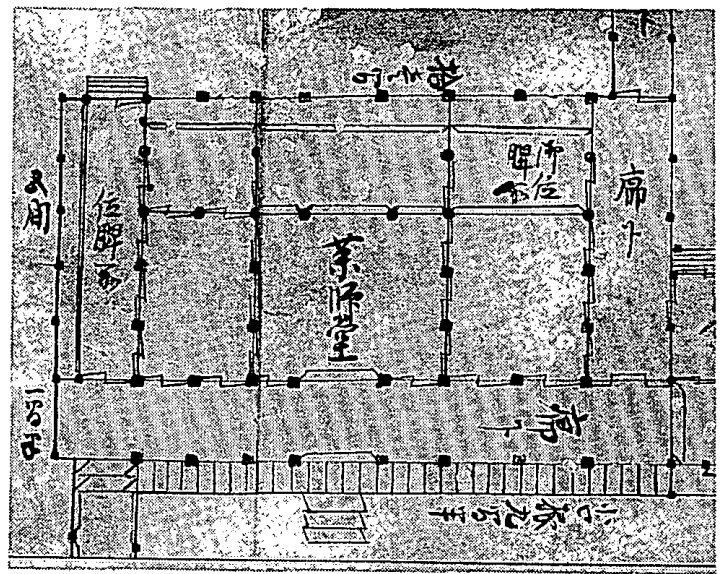

図一9「福厳寺惣地指図」(立花和雄氏蔵) 中の薬師堂

の現本堂は柳河藩主の苦提寺の位牌所としての機能に応 じた建物なのであって, 福厳寺の黄檗派寺院としての本 尊を祀るための本堂は，先記した大雄宝殿であると考え られる。

なお，二列三間六室の方丈型平面をもつ古図の「薬師 堂」は恐らく黄檗派へ転派する以前の寺院から踏襲した 堂宇名称や平面であって，その中尊であった薬師仏も古 い時代のものと言われている主26)。

現在この茼堂の中で中尊が釈迦仏であり両脇侍が阿 難・迦葉両像と変わっているのは, 明治初年頃の大雄宝 殿等の解体にあたって, 大雄宝殿の背後にあった「丽堂」 へ合祠する際に，薬師仏を脇に移座させ，黄啋派寺院と しての本尊釈迦仏を中尊とし，ここに「嗣堂」を「本堂」 と称する経過をたどったものと考えられる。

故に，この現本堂が採用する二列三間六室の方丈型の 平面が，当福㛜寺で当初からの計画として，黄檗派寺院 の本堂として採用されたものではない。

口. 河北山常楽寺の本堂

黄檗派寺院を除く曹洞・臨済両禅宗寺院において江戸 時代に頻繁に見られる二列三間六室の方丈型平面の本堂 は，当地方の現在使われている本堂中に完全な例は 1 例 も見られない。

しかし，その存在が本山萬福寺蔵の明治 13 年 (1880) 頃の『寺院明細帳」に載る間取り図より窥える。

河北山常楽寺は，福岡県山門郡山川町河原内にあった が，現在は廃寺となっている。当寺は宝永元年 (1704) 鉄文の法嗣であり福厳寺第二代住職であった玄堂元要を 開山として創設し, 天保元年 (1830) 福厳寺第 10 代住 職であった富峰如嶺が再建したと伝える主12)。

図一10 はあまりにも簡略な図であるが，その間取り のあり方は，二列三間六室の方丈型本堂のあり方を示し ていると考えられる。ただし，六室のうちの一室が2つ に分割されているし，中央にある「佛間」と「佛檀」は 入れ換った方が理解し易い。いずれにしても，二列三間

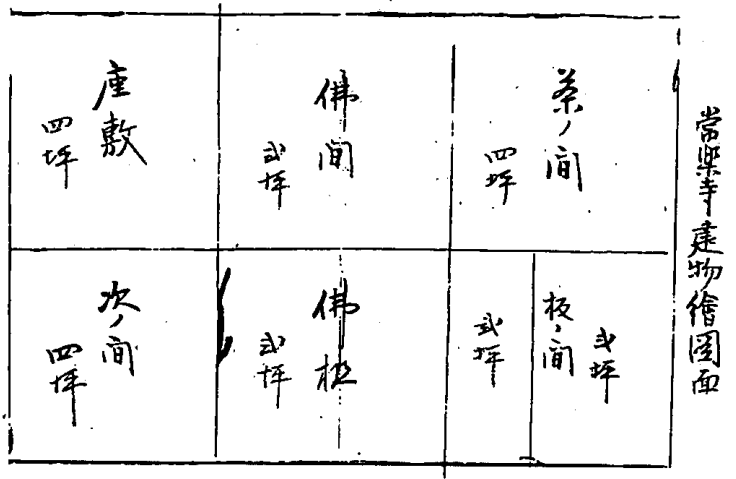

図一10「寺院明細帳」(本山萬福寺文華殿蔵) 中の常楽寺本堂

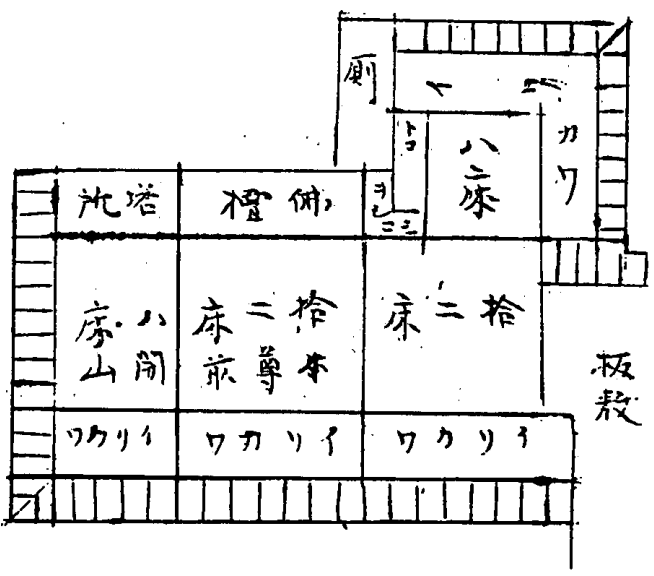

図一11「寺院明細帳」(本山萬福寺文華殿蔵) 中の正法寺本堂

六室の方丈型本堂に近い平面ということは言える。「常 楽寺建物繪圖面」と記されてているが，当図のみしか常楽 寺の所には揭げられていないので, 本尊は当然この困中 の「仏檀」に㳙られると考えられて，この図が本堂の間 取りを示していることになる。

明治 13 年 (1880) 頃の「寺院明細帳」の中には, 方 丈型の本堂の平面を示すものは, この常楽寺の他にも, 次の 2 寺がある (所在地は現在のもの)。

・宇治山通玄寺（大牟田市吉野 673）本堂

- 竜宮山福聚庵（福岡県三池郡高田町黒崎開 1954） 本堂

うち, 後者の福聚庵本堂はその一部の遺構が残つてお り，方丈型の本堂の正面中央に突き出して付設される差 し架け屋根の出入口部における紐部形態から, 江戸時代 末期頃の建物と推定される。

八. 仏頂山正法寺の本堂

当寺は, 福岡県山門郡山川町大字河原内 273-1 に所在 する。享保元年 (1716) 鉄文の法嗣 - 悦堂元逸の創設と 伝える主12)。現在の本堂は新しい。明治 13 年 (1880)の 「寺院明細帳」に記載される書院などを含む全体の間取 り図の内の本堂部分だけ取り出すと, 図一11のように なる。南面しており, 南と西の両面に縁を付しており, 北東隅と東側へ別室や庫裡等が接続している。中央奥に 
「佛檀」を構え，本尊前に「拾二」帖の室を置き，西側 に接して，開山（悦堂元逸）の場所として前方に「八」 帖の室を設け，「佛檀」の前方の間の東側に「拾二」帖 の室を置き, 当室の奥には「八」帖の座敷が付く。南側 の半間通りが入側となっている。

当平面は，確かに奥の室が同じ奥行きとなっていない ので整然とした二列三間六室の方丈型本堂ではないが, 二列三間六室の方丈型本堂の簡略型とすることもできる と考えられる。

二、塔頭・別峯院の客殿（方丈）

本山萬福寺には, 鉄文および弟子達の宿院としての別 峰院が鉄文在世の延宝 3 年（1675）3 月，既に建てられ ている。それで当別峰院は, 筑後地方南部の各寺院との 関連は密接なのである。

当別峰院の中心的建物である客殿が二列三間六室の方 丈型本堂の平面をしていたのである。創建当時の建物か どうかは不明であるが, 秋篠文夫氏蔵の古文書中の『黄 檗山塔頭別峰院方丈庫裡等建直し御願』という延享元年 (1744）5 月の図にのる方丈主33) および当図とほぼ同じ 平面をもつ天明 8 年 (1788) の萬福寺蔵の客殿の図があ る ${ }^{\text {淁 }}$ 。後者の客殿の図（図一12）を見ると, 正しく典
型的な二列三間六室の方丈型本堂の平面をもっている。 南面している当客殿の東側に付設の開山堂は当然別峰下 の祖・鉄文禅師の墓所である。

木. まとめ

完全に保存されている実例は 1 例もないが, 筑後地方 南部にも, 明治 13 年（1880）頃には二列三間六室の方 丈型の本堂形式が採用されていたことは指摘できた。

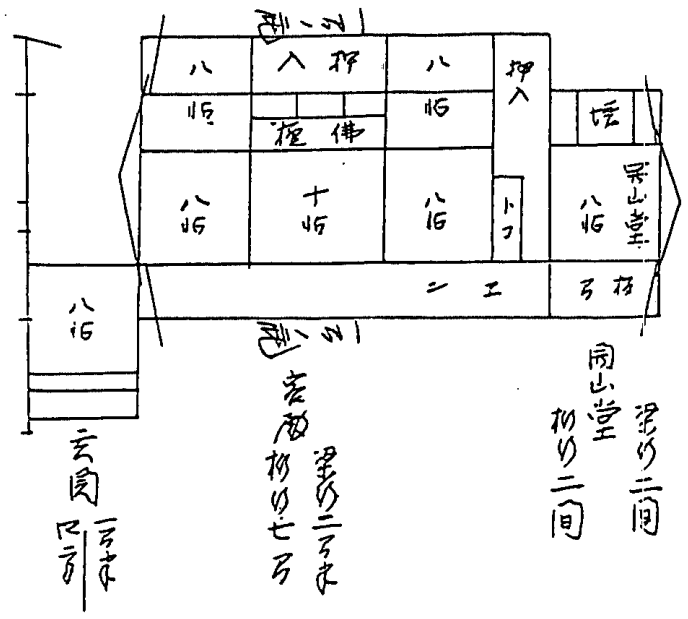

図一12【諸伽藍并塔頭繪圖』（本山噧福寺文華殿蔵）中の別峰 院客殿

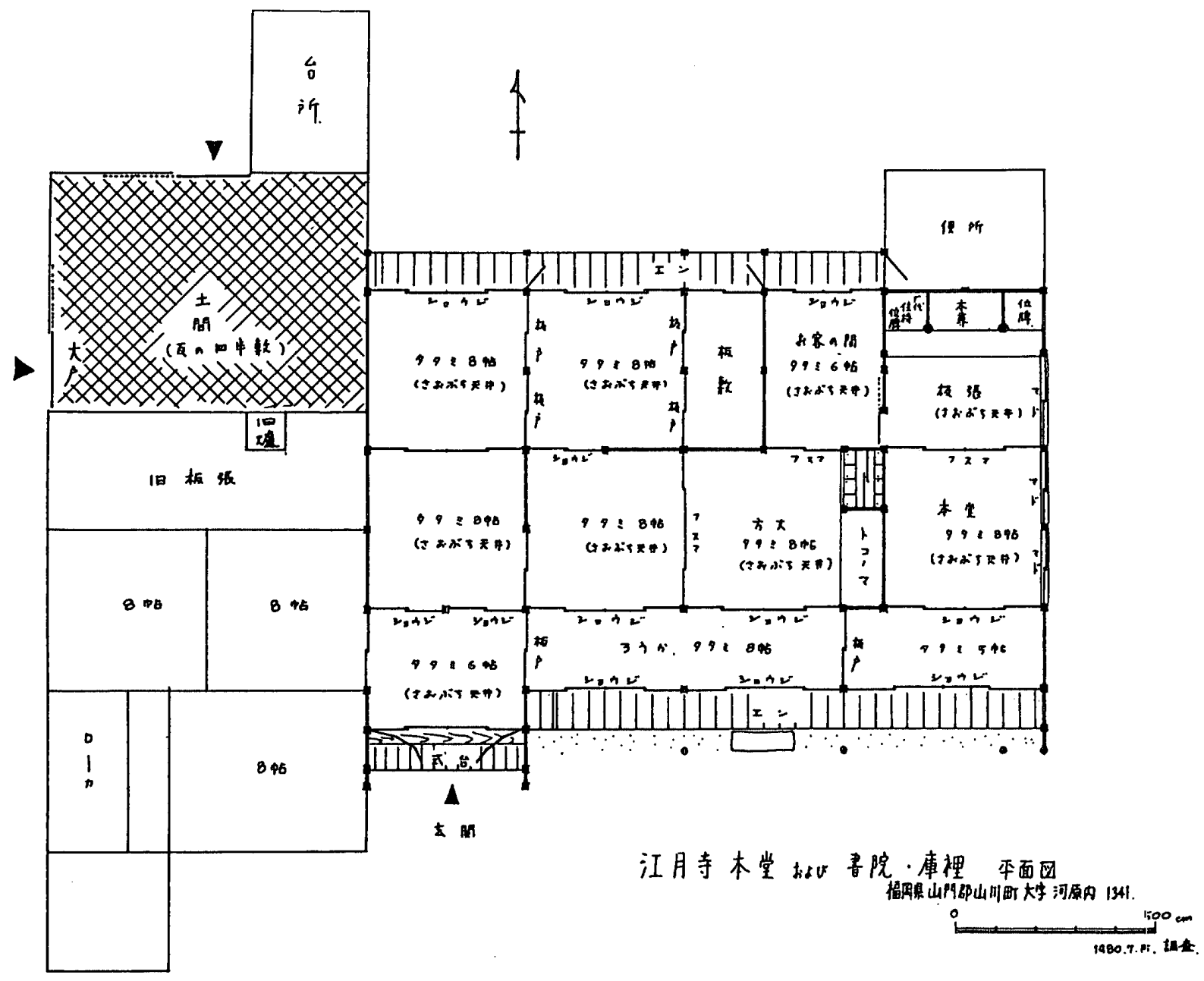

図一13 江月寺本堂の現状平面略図 (筆者製図) 
福聚淹本堂の一部残存遺構の推定年代によってここの ような方丈型の本堂形式は，江戸時代末期には当地方で も採用されていたと考えられる。

\section{5. 座敷本堂}

当地方で座敷本堂と呼ばれている別の形式の本堂があ る。以下，具体的に実例を掲げる。

イ. 松濤山江月寺の座敷本堂.

松濤山江月寺は, 福岡県山門郡山川町大字河原内 1341 にあって，随分と人里離れた山奥に所在する。寛 文 12 年 (1672) 福岡県三池郡高田町江浦で創立され, 元治元年 (1864) 年現在地に移転されたと伝えられる ${ }^{\text {(12) }}$ 。 移転時の住持が, 本山萬福寺の住持ともなった独唱真機 であり这35)，この独唱禅師は福厳寺の第 14 代住職にも なった。

当寺の現本堂は，今まで述べてきたいずれの本堂の形 式とも異なっている。屋根の主要部分は旧状草荣の寄棟 屋根となっている。平面は図一13である。間取りは, 北西部に㙛の四半敷の土間とした台所部分があり，この 土間に接して板張りの大きな空間がある他は，全て小さ な和室に分割されている。建物は南面している。式台付 きの玄関が構えてある。この玄関に両開き扉が付いてい ることは，当地方の格式を重んじる伝統的住宅とは異な る。内部の各室のあり方は，伝統的住宅とほとんど変わ らない。入側縁がある。床の間や違い棚等の座敷飾りを 揃える 8 帖の部屋は，一般の伝統的住宅では座敷にあた るが，「方丈」と呼ばれている。これらの部分までなら 僧侶でない一般世俗人の住宅にも見られるものである が，この「方丈」のさらに奥に寺院としての「本堂」と 呼ばれている部分が設置されている。しかし，この「本 堂」も伝統的住宅の部屋構えをとるに過ぎない。すなわ ち，奥（北側）室の $2 \times 2$ 間は奥壁に接して仏壇を設け て中央に本尊を脇に位牌を祀り，仏壇前方は板張であり， 天井は棹縁天井である。前（南側）室は引違いの襖で仏 壇のある奥室と隔てて， $2 \times 2$ 間すなわち 8 帖の畳敷き であり，棹縁天井の部屋である。さらに南側には，障子 で隔てて入側縁が付く。確かに，この棟においては，こ の「本堂」の部分が一番上位の位置を占めていると考え られ，伝統的住宅の中に占める位置において，一般世俗 人の用いる仏間とは異なるとも考えられる。しかし，こ の「本堂」における休高と内法高はじめ，壁・床および 天井の在り方は,「方丈」は勿論他の部屋とも変わらず, 伝統的住宅の部屋構えと異ならない。当江月寺本堂には 屋根裏に独唱禅師自身が書いた上梁銘があっで住36)；文 久 2 年 $(1862)$ 上梁亡分かり, 建築様式もその頃のもの と推定される。

こうした本堂の形式は，従来まったく知見にないもの である。

当寺は所在地が山奥深くにあるため，独唱禅師が山に
引き籠もる隠居のための寺として建てたとも考えられ る。しかし，同じような形式の本堂は，以下に実例を揭 げるように，当地方においてはその他にもかなり多くあ り，座敷本堂と呼んで親しまれているき37)。

口. その他の座敷本堂

本山萬福寺蔵の明治 13 年 (1880) 頃の『寺院明細帳」 を調べると，次の 2 つの寺院の本堂もこの座敷本堂にあ たる。

・臥雲山太梅庵（大车田市大字上内南 936）本堂

・霊明寺（既出）本堂……これは，既に述べた寛政年 間(1789 1801)頃の図に描かれた土間式本堂(「佛 殿」）がこの『寺院明細帳』の座敷本堂へ変更さ れたものと考えられる。何故なら，古い「雪峰山 図」の土間式本堂である「佛殿」は，「寺院明細帳」 には記載がない。

しかし, 上記 2 寺の座敷本堂は現存しない。 八. 北関山崇寿寺の座敷本堂

北関山崇寿寺は, 元禄元年 (1688) 鉄文の開山とし開 始され, 福岡県山門郡山川町北関に昭和 20 年代まであっ たが，今は廃寺となってしまったと言われるき12)。明治 13 年 (1880) の「寺院明細帳」に記載の図は図一14の ようである。本堂の向拝は南面する。北側へ四帖さらに 八帖之各室が続き，一番奥にある十帖畳敷きの伝統的住 宅の部屋に寺の本尊を祀る仏壇がある。しかも，仏壇は 奥壁にあたる北壁にはなく，東壁を突出させて仏壇を設 置してある。この十帖畳敷きの部屋では，この仏壇が伝 統的住宅の座敷における床の間の位置を占めて, 仏壇脇 の北側には座敷飾りの「ショイン」(「書エン」と記され る)さえ付設される。当室は「客殿」と名付けられてい る。

\section{二. 桐林山鳳来寺の座敷本堂}

こうした座敷本堂と呼ばれる形式の本堂は，次の寺に も現存するが，明治 13 年の「寺院明細帳】の間取り図 と異なるために江戸時代の本堂ではないと考えられるの でここでは平面図を揭げない。

- 天瑞山吉祥寺（福岡県山門郡山川町大字立山 1049） 本堂

- 福聚山法輪寺（大牟田市大字上内 2245）本堂

明治 13 年 (1880) の「寺院明細帳」とほぼ同じ平面 で残存するのは，桐林山鳳来寺 (大车田市岩本) の本堂 である。鳳来寺は慧日寺（既出）の山内寺院の 1 つであ る。享保 11 年 (1726) 柳川において創立されたが, 安 政 2 年 (1855) に現在地に移転したと言われるき12)。図 -15 が現状の平面図である。ほぼ南面する。東側にさ ほど大きくない土間部分があって大戸の入口があるが， 別に玄関をもつ。一番奥の部屋は南側に縁側を付けた伝 統的住宅の座敷にあたる部分である。当室には床の間もも 設置されている。この室は「本堂」と呼ばれている。こ 


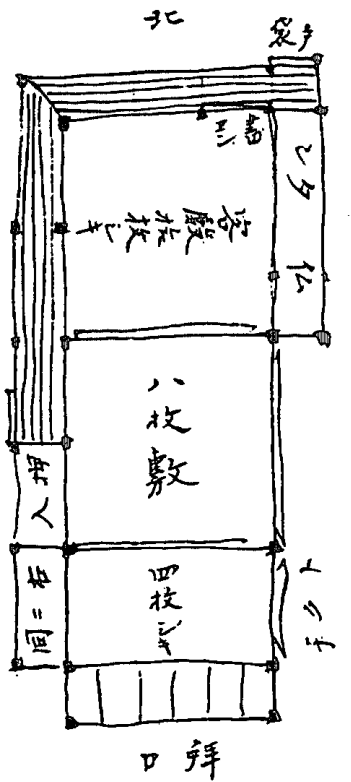

4

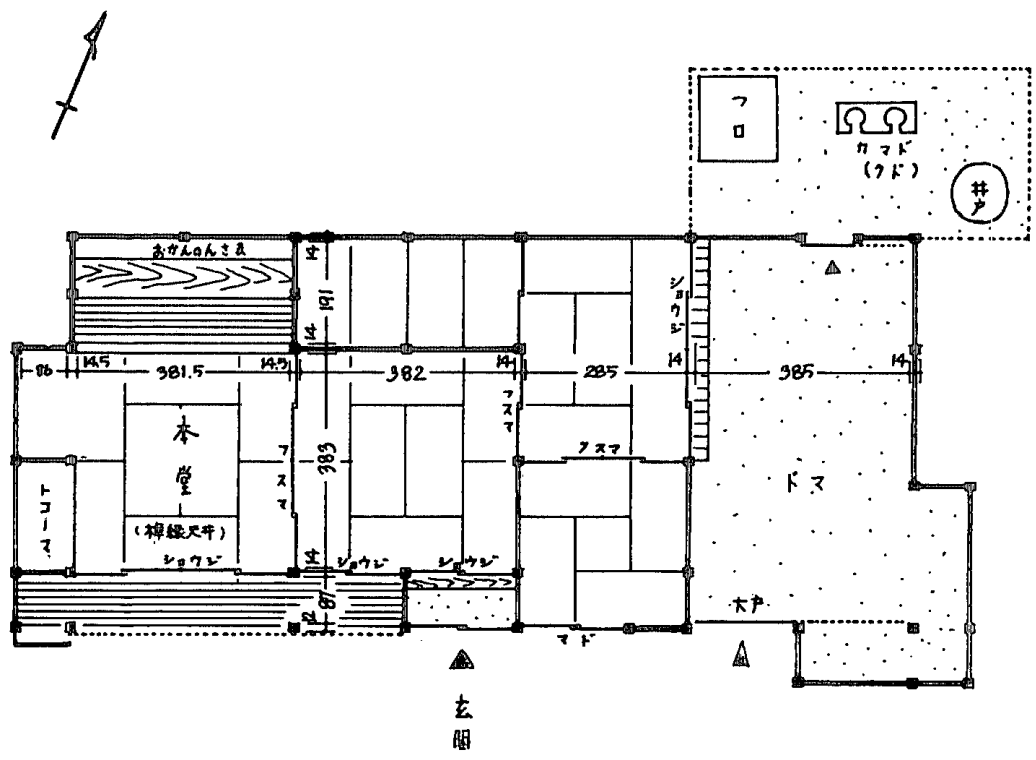

俤来寺

大牟田市岩本

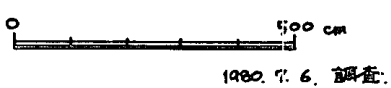

图一14「寺院明細检」(本山萬福寺文華殿蔵) 中の崇寿寺本堂

図一15 槄来寺本堂の現状平面図（筆者製図）

の部屋の北側の奥行き 1 間部分には板敷きの奥に仏壇が 構えてあり，この仏壇の上に寺の本尊観音像が祀られて いる。当堂は, まさしく座敷本堂の名に相応しい構成で あると考えられる。当本堂は, 江戸時代最末期頃の建物 と推定される。

\section{木.まとめ}

江月寺本堂と鳳来寺本堂が具体的な現存する座敷本堂 の実例である。前者は，「本堂」と呼ばれている本尊を 祀る部屋が座敷飾りをもつ「方丈」と呼ばれている座敷 構えの部屋とは別室となっており，しかもこの「方丈」 より上位に置かれているが,「本堂」の建築的構成は「方 丈」と同じく伝統的住宅の在り方と同様である。後者は， 「本堂」と呼ばれている本尊を祀る部屋は床の間をもつ 來敷と共用の椂子を呈している。両寺本堂ともに座敷本 堂の名前によく適った本堂の形式と考えられる。

このような座敷本堂が黄檗派寺院で採用された年代が 判明するのは, 江月寺本堂の上梁の文久 2 年 (1862) ば かりではない。霊明寺においては寛政 2 年 $(1790)$ には 土間式本堂であったのが明治 13 年（1880）には座敷本 堂となっているので, この霊明寺の座敷本堂も 19 世紀 になってから出現したと考えられる。鳳来寺現存本堂は 寺が現在地へ移転してきた安政 2 年 (1855) 以降と考え られる。

\section{まとめ一筑後地方南部における黄檗派寺院の本堂形式と その変遷}

鉄文道智を祖とする別峰下に全寺院が属しているまと
まった地域である筑後地方南部における黄檗派持院の本 堂形式について, 遺構・古絵図・文献等の資料を収集し て, 具体的に江戸時代における本堂形式を分類し, 併せ て各本堂の建設年代をも考えた。そこで, 当地方におけ る黄檗派寺院の本堂形式とその変遷を次のようにまとぬ ることができる。

まず，当地方における中枢的寺院（禅堂を 1 つの独立 した建物としてもつ寺院）である梅獄山福厳寺の大雄宝 殿が, 本山萬福寺の大雄宝殿と同じ本堂形式で廷宝 2 年 （1674）までには当地方に出現したと考えられる。平而 の在り方, 平面規模の大きさおよび揭げられた対聯文言 の内容等の類似から, 福厳寺の大雄宝殿は本山糔福寺の 大雄宝殿と同様な外観屋根二重であったことが推測でき! る。本山萬福寺大雄宝殿との違いは, 中央部に拈ける丸 柱の使用である。

続いて, 当地方では福厳寺大雄宝殿の出現に続いて, 土間式本堂が多く建設され続けた。江戸時代の前期と中 期における本堂形式を知る資料がなく，後期の土間式本 堂についても沢山の実例を指摘することができないが, 霊明寺本堂のような小さな本堂さえ土間式本堂であった ことから判断して江戸時代の中期頃までの本堂は土間式 本堂であったと推測できる。中期以後, 後期になっても 土間式本堂は建設されている。

しかし，土間式本堂ばかりでなく，禅林寺本堂のよう な，床を張る一室の独立した本堂が，遅くとも文政年間 (1818３0）頃加採用されている。この本堂形式の開 始である江戸時代後期からやっと床が張られるようにな 
り,当地方の黄檗派寺院における本堂形式に新しい動き が始まったと考えられる。

次に，江戸時代末期頃から，禅宗他派の本堂形式にも 共通する二列三間六室の方丈型の本堂形式が採用されて いる。

さらに，座敷本堂と呼ばれている本堂形式がある。こ の本堂形式は，座敷本堂という呼び名の通り，伝統的住 宅に同化せんばかりの親しみのある本堂形式であり, 江 戸時代末期から盛んに用いられた。

以上が，具体的資料を用いて忠実に解明を試みた筑後 地方南部における黄檗派寺院の本堂形式の変遷である。 江戸時代後期以降のみに大半の資料が集中している。さ らに，はじめに述べたように小さい寺院がほとんどであ るため史料の収集は困難であった。しかし，こうした小 寺院をも含めて本堂形式について, 筑後地方南部の黄檗 派寺院においては以上のような変遷が行われていること が具体的に解明できた。

なお，本稿では本堂の形態面での形式のみについて注 目している。本堂形式がもつ象徴的意味も考えられるが, 黄檗派寺院でこれを語る資料を今何ももっていない。今 後, 別峰下の禅僧の語録等の中に関連する資料を探し出 せれば，具体的に検討できるかも知れないが，今後の課 題としたい。

終わりに，本稿を成すにあたっては，九州大学教授前 川道郎氏と九州歴史資料館八尋和泉氏には大いにご教示 を受けた。また，黄檗宗寺院関係では，故田谷默雷，林 雪光, 中尾文雄, 鳥越文邦, 宮崎旭常, 龍岡弘道, 花岩 スエ子, 花岩友樹, 常磐英之の各氏をはじめ, 多くの方々 のご教示を恭なくした。記して，深く謝意を表す。

本研究の成果の一部は, 文部省科学研究一般研究 (C) 「九州地域における黄檗宗寺院建築の歴史的展開過程に 関する研究」(代表者 山本輝雄)による。

注

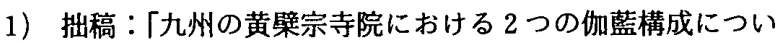
て」(旧本建築学会計画系論文報告集」第 389 号, 昭和 63 年 7 月）と拙稿：「九州の黄藩宗寺院における門形式 および天王殿の位置と向きについて」(「日本建築学会計 画系論文集」第 415 号, 平成 2 年 9 月)。

2）代表的なものは，飯田須賀斯：「中国建築の日本建築に及 ぼせる影響」(昭和 28 年 10 月, 相模書房) や桜井敏雄, 大草一愳：「黄檗宗寺院の伽藍計画に関する研究一法雲寺 の建築と伽藍計画を中心として一」(美原町史紀要【美原 の歴史」特別号, 昭和 58 年 3 月, 美原町教育委員会)。

3) 竹貫元勝：「近世黄檗宗末寺帳集成】(平成 2 年 6 月, 雄 山閣出版)。

4) 田谷黙雷: 「檗林集」(昭和 42 年 3 月, 聖福寺)。

5）林 雪光：〔黄檗文化」(昭和 47 年 3 月, 黄鍳山萬福寺) の p. 20。

6) 辻善之助：「日本佛教史 近世篇之二」(昭和 28 年 3 月, 岩波書店) の p. 340 。
7)「前揭注 3 書」の pp. 25 30「黄檗宗の宗勢」。

8）【黄檗宗寺院名簿」(平成元年 3 月, 黄檗宗務本院)。

9)【前揭注 4 書」所収。

10）拙稿：「南筑後地方における黄檗宗寺院建築の展開」(「筑 後柳川福厳禅寺一付. 筑後の黄檗寺院一」, 昭和 60 年 3 月, 九州歴史資料館）と拙稿：「南筑後地方における黄檗宗寺 院建築の展開 付. 筑後の黄檗宗寺院建築目録」(「黄檗 文庫」No. 82 , 昭和 60 年 7 月, 萬福寺文華殿)。

11）大慈山慧日寺（福岡県大车田市大字岩本 2589）蔵の「壬 申年慧日寺記録」。同文書の閲覧にあたっては, 同寺住職・ 鳥越文邦氏に大層お世話になった。記して，謝意を表す。

12）鳥越文邦：「費隠禅師亡其の著, 五燈嚴統一附. 筑後の黄 檗一」(昭和 61 年 8 月, 大慈山慧日禅寺)。

13）【福厳開山鐵文樿師」（昭和 11 年 4 月，福厳寺）の p. 4。

14）鉄文禅師の伝記は，近年でも数種でている。そのうちの 1 つは次のものである。中尾文雄：「福厳開山鉄文禅師伝」 (昭和 61 年 6 月, 梅獄山福厳禅寺)。

15）同書の板木 (版木) は, 福厳寺の奥深くに蔵される。筆 者閱読のものは，かつて，この板木（版木）を用いて刷 られた黄檗研究の大先達・門司の故吉永雪堂氏のものの コピーである。同書の内容については, 現福厳寺住職・ 龍岡弘道氏にご教示を受けた。記して，謝意を表す。

16）次のように見える

「延賔甲宙年大雄寶殿選佛場禪悦堂方丈菲堂浴房衆尞一新 樂成」。

17）当図について，柳川古文書館の中野等氏にご教示を受け た。記して，謝意を表す。

18）【重要文化財萬福寺大雄宝殿・禅堂修理工事報告書」(京 都府教育庁指導部文化財保護課編集, 昭和 45 年 3 月)。

19）拙稿：「梅孰山福厳寺開山・鉄文禅師の捉えた萬福寺の伽 藍構成」(「日本建築学会大会学術講演梗概集 (中国)」, 平成 2 年 10 月)。

20）中尾文雄訳：「黄檗清規」(昭和 59 年 7 月, 黄檗宗務本院) の p. 70。

21）【前揭注 14 書」の p. 65。この対聯は, 実物および原本と もに福厳寺にある。

22）ここでは，福铰寺大雄宝殿を他の土間式本堂と別の一分 類とするための資料として揭げたものであるので,さら に深く検討しない。黄䇒派寺院におけるこの対聯文言と 大雄宝殿の荘厳化についての考察は, 別に論じる予定で ある。

23）【禅学大辞典」下巻(昭和 53 年 6 月, 大修館書店)の p. 818。

24）当文書の閲覧およびコピーなどにあたっては，本山萬福 寺文華殿の林雪光先生はじめ瞕貣の方にお世話になった。 記して，謝意を表す。

25）後述する宗永寺本堂（図一7）がこの土間式本堂に入るこ とになれば，土間式本堂は 1 例増えることになる。

26）「柳川福篇寺歴史資料調查報告書一付. 筑後の黄檗寺院一」 (昭和 58 年 3 月, 福岡県九州歴史資料館)。

27）【福岡県の近世社寺建築一近世社寺建築緊急報告書一」(昭 和 59 年 3 月, 福岡県教育委員会)。

28）「柳川藩史料集】(中島政治編，昭和 56 年 3 月，青潮社）

29）【旧柳川藩志」（柳川・山門・ 三池教育会編，昭和 32 年 3 月)

30）大梘幹郎 - 加藤正俊 - 林 雪光：「黄檗文化人名辞典】(昭 和 63 年 12 月, 思文閣)。 
31）横山秀哉：『禅の建築」(昭和 42 年 3 月, 彰国社)の p. 156。

32）例えば, 柳河藩では, 安政 7 年 (1860) の崇久寺本堂 (柳 川市東浦池 147 の 1) などに現存している(「前揭注 27 書」 の p. 156)。

33）秋篠文夫氏蔵文書中の延享元年（1744）5月「黄檗山塔 頭別峯院方丈庫裡等建直し御願」の方丈が二列三間六室 の方丈型本堂の図である。当図は, 字治市歴史資料室・ 岡井毅芳氏のご教示にて，昭和 59 年 (1984) 8月 31 日, コピーを拝見した。ご教示に対し，記して謝意を表す。

34）萬福寺蔵『諸伽藍并塔頭繪圖」（天明八年=1788）も同様 な図である。当資料については, 京都大学研究員・山野 善郎氏にご教示になった。記して, 謝意を表す。この萬 福寺蔵の史料閲覧にあたっては, 萬福寺文華殿・林雪光 先生はじめ職員の清水ことえ, 俣野浩子両氏にお世話に
なった。記して, 謝意を表す。

35) 鳥越文邦:「独唱真機和尚略伝」(「黄檗文華」No. 12, 昭 和 49 年 10 月)。

36）上梁銘について筆者はいまだ実見していない。銘文につ いては，現住職・花岩スエ子它にご教示頂いた。また， 大车田市歴史資料館館長佐藤和四郎氏からもこの上梁路 に関するご教示を受けた。記して，謝意を表す。

37）この “座敷本堂”という呼び名がどの地方に，またどの ような宗派に広がっているのか，不明である。この語は， 慧日寺住職・鳥越文邦氏にご教示を受けた。記して, 谢 意を表す。

(1990年 7 月 9 日原稿受理, 1991 年 1 月 28 日採用決定) 